\title{
Strategies in Coping with Bilingual Instructions Among Science Students in Malaysia
}

\author{
Siti Hamin Stapa \\ Abdul Rauf Suhaimi
}

Faculty of Social Sciences and Humanities, National University of Malaysia

doi: 10.19044/esj.2017.v13n16p174 URL:http://dx.doi.org/10.19044/esj.2017.v13n16p174

\begin{abstract}
Bilingual instructions are used in classrooms in assisting the learners towards their comprehension of the content delivered. However, the strategies applied by the learners to cope with this kind of instructions are less discussed particularly in the science classrooms. The science courses offered at the National University of Malaysia use bilingual instructions, which are English and Malay. This paper, therefore, aims at investigating the strategies applied by such students. It also aims at examining the students' perception towards the use of bilingual instructions at the university. 60 low proficient ESL students from the School of Environmental and Natural Resource Sciences, Faculty of Science and Technology, National University of Malaysia were involved in this study. Semi-structured interview was conducted with 4 respondents from the four majors offered by the school in order to gather data. The results revealed that the students mentally translated the bilingual instructions, made inquiries to the lecturers and peers, referred to Google Translation as well as dictionaries in coping with the bilingual instructions. When asked about their preferences, most of them preferred the use of bilingual instructions as it helped them in understanding the science subjects. The study suggests that the students should be equipped with an adequate proficiencies in both languages so that they can successfully understand the lessons using bilingual instructions.
\end{abstract}

Keywords: Bilingual instructions, learning strategies, students’ perceptions, low proficient students

\section{Introduction}

The purpose of this research is to investigate the strategies applied by the limited proficient English learners of Faculty of Science and Technology to cope with bilingual instructions in science classrooms. It is considered important to reveal the strategies as it will give us clearer picture on how 
these students learn and comprehend the subject matter taught in two different languages.

The implementation of using ne particular language as the medium of instruction in the teaching of Science and Mathematics in Malaysian education system has been altered several times in the past till the recent time. Due to the concerns that there are huge and paramount needs to empower the proficiency of English Language amongst the Malaysian students, the former Prime Minister, Tun Dr Mahathir bin Mohamad, in 2003, had introduced a policy which stated that these two critical subjects would be taught in English Language onwards. Following this announcement, the implementation of English as the language of instruction for the teaching of Science and Mathematics started in 2003 for Year 1, Form 1, and lower six (Lan and Tan, 2008).

However, due to some reasons, this policy had caused fairly severe objections from the citizens, academicians, politicians, as well as the nationalists. Skepticism that grew upon this issue was due to the fact that for years, the teachers had been trained to teach these subjects in Bahasa Malaysia and the sudden quantum leap to change the norm could not suitably fit into the Malaysian context. It was deemed as a trifle ambitious education plan for the nation which did not holistically take into consideration the students' proficiency levels in English Language, particularly those from the rural areas. People were also in the state of dilemma whether to proceed enforcing the use of the national language to maintain national identity or to encourage people to be more proficient in English in order to compete in the globalized world (Ha, Kho, and Chng 2013).

By voicing that Bahasa Malaysia must be prioritized in the education system, they demanded for the alteration in the previous policy by which pressing the needs to teach these subjects in the national language, Bahasa Malaysia. Subsequently, in 2012, the Deputy Prime Minister, Tan Sri Muhyiddin Yassin announced a revised policy which instructed that these two subjects would be taught back in the national language. As far as the matter is concerned, this indecisive policy has somehow or rather disrupted the learning process of the students.

At tertiary level, these subjects are on the contrary taught in English Language. However, the case is slightly different in the National University of Malaysia (UKM). Since this university still strongly upholds the use of Bahasa Malaysia in its education system, the instructions in the science classrooms have to be delivered in this language. Nonetheless, with realization that English is an important international language for the trade and transfer of scientific knowledge (Gill 2004, cited in Asiah 2013), the educators find that there is a huge need to incorporate the use of English in teaching content along with Bahasa Malaysia. This improvised method of 
teaching is hoped to give adequate exposure of the scientific knowledge to the students from a global perspective as well as to help them to comprehend the content better. As a result, the instructions are given bilingually. A number of researchers have conducted their studies on the effectiveness of bilingual instructions towards learning. However, lesser attention is given to the aspects of how do the students cope with and perceive the use of bilingual instructions in their learning.

In the Faculty of Sciences and Technology (FST), and the National University of Malaysia (UKM), the use of bilingual instructions in science classrooms is practiced largely by the lecturers. These science subjects are taught in both languages, English and Bahasa Malaysia. At times, the use of Bahasa Malaysia surpasses the use of English Language. The students do not only encounter bilingual instructions in classrooms. In fact, they have to deal with this when doing revisions, completing assignments, sitting for quizzes and examinations, and when writing their fundamental theses in their final year. Lopez and Patricia (1992) pointed out that with the increasing awareness of bilingualism, language policies are being created and educators tried to redesign curricula to better serve the needs of language of the minority students. However, encountering with bilingual instructions is not always easy. Considering that the students' proficiency levels of English are varied, the comprehension of the content taught might also be affected. This has led the researcher to hypothesize that the ability to cope with bilingual instructions depends on the language proficiency of the students.

\section{Definition Of Bilingualism}

In the new landscape of rapid urbanization, communication between an individual with another is no more only occurring between parties of similar cultural backgrounds. Instead, the communication occurs crossing the borders of different cultures and languages. To enable this, acquisition in the second or foreign language is imperative. An individual who is incapable of mastering at least one second or foreign language is often regarded as handicapped. Therefore, people nowadays are doubling their efforts to acquire and attain proficiency in other languages. This occurrence together with the growth of knowledge in language studies have significantly contributed to the emergence of a term, bilingualism. Basically bilingualism entails the ability to speak in more than one language. Bilinguals are often broadly defined as individuals or groups of people who obtain the knowledge and use of more than one language (Butler and Hakuta 2006).

This is supported by Baker (2011) who generally agrees that a bilingual is an individual who is capable of using two languages. It comprises the ability to speak, write, listen, and read in those two languages. These scholars further add that bilingualism is a complex psychological and 
socio-cultural linguistic behaviour and has multi-dimensional aspects. Similarly, Gottardo (2008) also shares his views with regards to the nature of bilingualism. He defines bilingualism as complex and is influenced by multiple factors such as the edge of acquisition of the second language, continued exposure to the first language (L1), relative skill in each language and the circumstances under which each language is learned. Since bilingualism is regarded as a linguistic behaviour, there will be uncertainties to what degree a person can be described as a bilingual. Certain questions, as raised by Butler and Hakuta (2006) for instance;

- "how much does one needs to know of more than one language in order to be qualified as a bilingual individual” and

- "what do we mean by knowing two languages"

serve as clear evidences to prove the flexibility of defining bilingualism. This is due to the fact that a type of behaviour cannot be measured numerically. Because there are no clear criteria to define a bilingual, various ways of defining bilingualism might come out, depending on the settings of the studies.

\section{Coping with Bilingual Strategies}

Knowing how the students cope with their learning is exceptionally crucial. This is supported by Mackeracher (1996) who states that the more we know the basic processes of learning and strategies used by an individual, the more effectively we can facilitate their learning. A number of researches (for example,Van Kraavenoord and Goos, 2003) investigated the strategies applied by the bilingual students to cope with reading task. Lavadenze (2003) in his research has revealed such results which are pertinent to this research. He discusses that the bilingual students of Spanish and English who are learning Spanish generally use contextual clues, decoding skills, and text structure to comprehend the unknown sentences. He further adds that the younger learners are, however, needed a greater amount of assistance to verbalize their thinking process. These younger learners usually have the propensity to utilize the strategies of pausing, self-questioning, rereading, and using context. He concludes that in order to understand a text that appears difficult to the learners, they need to employ metacognitive and metalinguistic strategies. In a similar research on bilingual students, Jimenez (1997) has mentioned the strategies used by the successful bilingual students to cope with reading tasks. He explains that these students are capable of transferring or applying their literacy knowledge and abilities from one language to the other. They also strategically implement this knowledge in a timely manner (Jimenez 1997). When encountering with unknown words of unfamiliar expression in English, they have well-defined strategies to cope with them. What we can simply deduce from this research is that the 
proficiencies of two languages can positively affect the academic achievement of the students. This is supported by the Common Underlying Proficiency (CUP) which is proposed by Cummins (2000) who claims that cross-lingual proficiencies can promote the development of cognitive and academic skills.

Padron (1992) has also conducted a study on the strategies applied by the bilingual students to cope with reading tasks. He has drawn the distinctive strategies applied by the good and weak learners when encountering with difficult reading texts. The seven good strategies according to Padron (1992) are:

- Summarizing in writing

- Underlining important parts of the story

- Self-generated question

- Checking through the story to see if you remember all of it

- Asking questions about the parts of the story you do not understand

- Taking notes

- And imaging or picturing the story in your mind

On the contrary, the weak learners tend to apply different strategies and there are as listed below:

- Thinking about something else while reading

- Writing down every word

- $\quad$ Skipping the part you do not understand

- Reading as fast as you can

- Saying every word over and over again

- Looking up words in dictionary

- And saying the main ideas over and over again.

Though in general these distinctive strategies as proposed by Padron (1992) might appear reliable, there are some uncertainties in the criteria of considering which strategies belong to the good and weak learners. Firstly, 'skipping the part that you do not understand' cannot be simply categorized as a weak learner's strategy. This is because anyone will tend to commit the same thing if there is limited time constraining them. This also applies to the strategy of 'looking up words in dictionary'. If the words a learner encounters are difficult, regardless of their intelligence and abilities, they must have to refer to the dictionary to look up for the definition. Therefore, this strategy appears to be used not only by a particular learner, but by most of them.

\section{Bilingual instructions}

Studies pertaining to bilingualism are usually conducted in the countries where the citizens are of plural societies. Christian (1994) has 
conducted a research to investigate the effectiveness of a two-way bilingual education. This two-way education program generally shares the aims of bilingual proficiency, academic achievement, and positive cross-cultural attitudes and behaviours (Christian 1994). In the research, she reported that the two-way bilingual education that was implemented in the schools around America had bore its fruition in promoting academic achievement for minority and majority students. This was due to the fact that the mediums of instructions used were intelligible to all students. Another compelling result had also revealed that the students hoped that the bilingual education would help to improve the relationships between the majority and minority groups. However she argued that while the approach works best when the numbers of students are balanced, they are many reasons why this may not always be feasible. Though the number of the students who are being enrolled into the programs might be considered balanced, the students' abilities might have been overlooked. This will rather affect the successful implementation of the bilingual education. The notion that bilingualism facilitates learning is further solidified by a research conducted by Zare and Mobarakeh (2013). Slightly in a different way of viewing the effectiveness of bilingual education, this research specified its scope to the English vocabulary learning of the students. They had conducted a research on the effects of bilingualism on L3 vocabulary learning among Iranian EFL learners. This study investigated whether Arabic-Persian bilinguals (APBs) took advantage of their bilingualism in learning the third language, English, versus Persian monolinguals (PMs). The participants had sat for a vocabulary test which was conducted to testify their recognition and production skills of vocabulary in English language. The recognition skills were tested by asking the participants to fill in the blanks with given answers at the bottom. Meanwhile, the recognition skills were tested by directing the students to give definitions of words given. The result illustrated that there was no significant difference in the recognition skills between the APBs and PMs. However, the APBs scored higher in the production skills. This, according to Zare and Mobarakeh (2013) was due to their ability to take advantage of knowing two languages in learning third language by associating third language words with related concepts and words in the first and second languages. On the contrary, the PMs could only resort to their first language. It reflected that the PMs were lacking the power of activating the passive knowledge (recognition) to produce communicatively well-formed strings of words. The results from this research prove that bilingualism brings positive effects towards the English vocabulary learning of the students.

In addition, by considering the social settings of Iran in general, this shows that a country with a diverse population (Parilah and Fauziah 2007) necessitates a more localized, flexible, and comprehensive educational 
courses to accommodate all the students' needs and expectations with different linguistic, cultural, and social background. Bilingual education, as proposed by Finch (2009). Amongst them are:

- Sufficient resources

- Educational opportunities

- Competent and qualified teaching staff

He then concluded that an effective infrastructure for implementation, a comprehensive support system, and an informed teachertraining program should be provided to ensure its success. Though his research is based on the Korean educational system of which English is treated as a foreign language, the aspects proposed by him are seen as universal and applicable to not only in a particular homogenous country like Korea.

\section{The study}

This study investigated the strategies applied by the students from the Faculty of Sciences and Technology (FST) in UKM to cope with bilingual instructions in their science classrooms. Another area that was covered was their perceptions towards the use of bilingual instructions. Therefore, a qualitative method was used to conduct this research. Interviews were conducted with selected students to get detailed information regarding the strategies they applied to cope with bilingual instructions.

\section{Sample}

There are five schools under FST; 1) School of Biosciences and Biotechnology, 2) School of Applied Physics, 3) School of Environmental and Natural Resource Sciences, 4) School of Chemical Sciences and Food Technology, and 5) School of Mathematical Sciences. The second year students from the School of Environmental and Natural Resource Sciences were Isample for this research. This particular school was selected because the frequency of bilingual instructions used in the classes under this school was reported higher compared to the other schools. Meanwhile, the second year students were chosen for this research due to their availability to be understudied since they did not have as packed schedules as the third year students.

\section{Procedures of gathering data Interview}

The interview sessions were conducted with four selected students from each major (Marine Science, 2) Environmental Sciences, 3) Biology, and 4) Geology). For the convenience of the students, the interview sessions were conducted in the languages preferred by them. This was to assist them 
in their expression of thoughts during the sessions. Another main reason was that they are the limited proficient English learners. Therefore, a fully structured English interview might not be suitable to be conducted with them. The session was also expected to take place within 10 to 15 minutes. However, the duration might be lengthened or shortened depending on the willingness of the students to answer the interview questions.

\section{Results and findings}

The investigation on the strategies applied by the science students to cope with bilingual instructions will provide us with a clearer picture of how they learn and comprehend the subject matter. This knowledge too enables the lecturers to facilitate their learning by using better approaches. The discussion of the findings will first address the strategies applied by these limited proficient English learners in coping with bilingual instructions. For that reason, four students from the School of Environmental and Natural Resource Sciences majoring respectively in the four majors which are 1) Marine Science, 2) Environmental Sciences, 3) Biology, and 4) Geology were interviewed to elicit the required data. The criterion for the interviewee selection was their results in the Malaysian University English Test (MUET). The four were the students who had scored Band 3 and lower in that English Proficiency Test. Respondent A is a male student from the Science Marine Program and he is 21 years old. Respondent B on the other hand, a male student, is from the Environmental

Sciences Program and 23 years old. Respondent C and D are both female students majoring respectively in Biology and Geology Programs. Both are also 21 years old. As for their results in MUET, three respondents obtained Band 3 and they are Respondent A, B, and C. Meanwhile, Respondent D scored Band 2 in that English Proficiency Test. Prior to the interviews, some open-ended questions were prepared regarding the strategies they applied to cope with bilingual instructions in their science classrooms. The interviews were conducted in both languages, English Language and Bahasa Malaysia in order to assist them in their expression of thoughts. Below are the results and findings obtained from the interviews.

\section{Question 1}

Do you faced any difficulties to understand the content of the lectures due to the lecturers' usage of bilingual instructions?

Most of the respondents admitted that they have faced several problems with this matter, but are still manageable. This is due to the fact that the unfamiliar scientific terminologies in Bahasa Malaysia are the ones that trouble them, not the context of the content. While bilingual instructions might sometimes assist them in their comprehension of the content, it 
however complicates their learning when it comes to completing their task/assignments. Respondent $\mathrm{C}$ mentioned that sometimes the assignments have to be written in Bahasa Malaysia even though they have earlier learned the subject matter in English. Respondent B also mentioned the difficulties they will have to encounter when writing their theses as they have to use Bahasa Malaysia instead of English.

Respondent A

Haah, susah jugak bila kami kena belajar dalam Bahasa Malaysia. Kadang kadang lecturers switch to English. But most of the time, lecturers speak in Bahasa Malaysia. Yang susahnya bila tiba-tiba lecturers guna perkataan Sains yang dalam Bahasa Malaysia. Lain sangat bunyinya. Lawak pun ada bila dengar.

TRANSLATION: Yes, it is quite difficult when we have to learn in Bahasa Malaysia. Sometimes, the lecturers will switch to speaking in English. But most of the times, lecturers will speak in Bahasa Malaysia. The tough part is when the lecturers use scientific terminologies in Bahasa Malaysia. They sound weird and funny too.

From the answers given by Respondent $\mathrm{A}$, it is understood that the problem which Respondent A faced is his inability to fully grasp the meaning of the difficult scientific terminologies. As he also added that some of these words sounded weird and funny to him, it tells the researcher that he is unfamiliar with these scientific terminologies, thus complicating his learning.

Respondent B

Biasa-biasa sahaja. Nak kata susah nak faham (tu) tak jugak. Sebab kami actually faham apa yang pensyarah (tu) nak sampaikan. Pensyarah pun banyak explain dalam English. Sebab kami dari sekolah dulu memang belajar Sains dalam English, so it's not so difficult (la). So... yeah, tak susah sangat. Tapi susah bila bab nak tulis thesis semua tu. (Kan) kami kena tulis dalam Bahasa Malaysia.

TRANSLATION: Just fine. Well, I am not saying that it is difficult to understand the lectures because we actually do understand what the lecturers are saying. Furthermore, they also explain about something more in English than in Bahasa Malaysia. It is not actually difficult for us to understand them because we already had the experience of learning science subjects in English during our schooling years, so it helps. However, it will be difficult for us to write our theses as we have to write them in Bahasa Malaysia.

Respondent B commented that his prior knowledge of learning Science subjects in English during his schooling years helped him to adapt to the bilingual teaching method in UKM. This therefore validates the 
Threshold Hypothesis proposed by Cummins (2000). The respondent's proficiency in English has enabled him to take advantage of bilingualism.

Respondent $\mathrm{C}$

Not so, because we understand what the lecturers are talking about. Ada juga pening-pening sikit. Sebab kami confused samada lecturers nak ajar dalam BM atau English? But faham (je) both languages. But bila nak buat assignments tu susah (la). Sebab kadang-kadang lecturers bagi assignments yang kena tulis dalam BM. Susah bila nak cari perkataan yang dalam English (tu) dalam Bahasa Malaysia. Jadi macam lambat sikit (la) bila nak complete kerja (tu).

TRANSLATION: Not much of a problem because we actually understand what the lectures are talking about. Maybe it is a bit confusing sometimes. It is so because we are unsure whether the lecturers want to teach the subjects in Bahasa Malaysia or in English. But both languages that are being used are still understandable to us. It is however difficult when it comes to completing our assignments. Sometimes they have to be written in Bahasa Malaysia. It is difficult to find the equivalent scientific and English terminologies in Bahasa Malaysia. Thus, delaying our task completion.

The lecturers' usage of bilingual instructions appeared to be nondistracting to Respondent C's learning. However, she mentioned that it was difficult for her to complete her assignments which had to be written in Bahasa Malaysia since she is not familiar with the scientific words in this language.

\section{Respondent D}

Susah jugak. Sebab saya dah biasa belajar dalam Bahasa Inggeris. Jadi, bila diajar dalam Bahasa Malaysia, saya jadi confused. Bukan nak kata saya tak faham, cuma ada (la) sikit-sikit perkataan yang pelik tu.

TRANSLATION: A little bit difficult. This is because I used to learn Science in English. So, when it is taught in Bahasa Malaysia, I become confused. Not to say that I do not understand it, but there are some words that appear weird to me.

Similarly, Respondent D also faced the same problem as Respondent $\mathrm{A}$ and $\mathrm{C}$ which was to understand the scientific terminologies in Bahasa Malaysia. This is due to the fact that she used to learn science subjects in English and a change in the language of instructions complicates her learning.

\section{Question 2}

How do you overcome this problem?

Several strategies to cope with bilingual instructions were mentioned by the respondents. Basically these strategies can be categorized into two categories which are: 
1. The strategies they apply to comprehend the lectures and

2. The strategies they apply to complete the tasks

In order to comprehend the lectures, the respondents would mentally translate the difficult scientific terminologies while at the same time try to understand the content of the lectures (Respondent B and C). They would also make inquiries to the lecturers if they did not understand certain words during the lectures (Respondent A, B and C).

The other party that they would make their inquiries to was their academically reliable peers (Respondent A and D). They had also applied some strategies when completing the tasks. Firstly, they would use Google Translate to search for the equivalent words in the target language.

Respondent A commented that this application is reliable. However Respondent B explained that the translation made by this application is not always accurate. They are times when the translation made by it sounds weird and funny. This leads the researcher to deduce that the accuracy of translation made by Google Translate is inconsistent. The other strategy as mentioned by Respondent $\mathrm{D}$ was also referring to dictionaries, though they might not be much of a help to them. This is because the definitions given by the dictionaries are more language-related.

Respondent A

Usually, saya akan tanya lecturers balik kalau saya tak faham perkataanperkataan tu. Tapi kadang-kadang kalau saya segan, saya just tanya kawankawan sahaja. Ada yang boleh tolong sebab (diaorang) pandaipandai English.

$\square$ Saya guna juga Google Translate. Boleh pakai juga application (ni).

TRANSLATION: Usually, I will ask the lecturers back if I do not understand those words. But, since I sometimes feel shy to do so, I will just ask my peers. Some of them can help us as they are good in English. *I also use Google Translate. This application is reliable for me.

The strategy that Respondent A used in order to comprehend the lectures was basically by making inquiries to the lecturers. This was done during the lectures, tutorials, as well as during consultations with their respective lecturers. However, as he sometimes felt shy to make inquiries during the lectures, he resorted to asking his friends. These are his peers who he regards are academically reliable. Nonetheless, being academically reliable here does not mean that they are only excellent in Science subjects, rather, excellent and proficient in English Language too. Meanwhile, the strategy that Respondent A used to complete his task was by referring to Google Translate. Generally, this application is designed to aid the internet browsers in translating words from a language to another. A wide range of languages around the world can be translated using the software. With regard 
to Respondent A's response, he commented that this application has been helpful to his task completion.

Respondent B

I will just translate dalam otak time lecturers tengah mengajar kalau ada sesetengah perkataan yang diguna oleh lecturer (tu) dalam English or dalam Bahasa Malaysia. Nak translate from English to Bahasa Malaysia tak ada masalah sangat. But it is difficult to translate from Bahasa Malaysia to English. Sebab perkataan Bahasa Malaysia yang kami dengar (tu) pun kami tak pernah dengar sebelum ini.

Sometimes I also ask the lecturers. But not always.

Google Translate saya ada guna juga. Tapi translationnya of course macam

tak betul sangat.

TRANSLATION: I will just mentally translate those difficult words whether in English or in Bahasa Malaysia during the lectures. I find that translating words from Bahasa Malaysia to English is harder than translating words from English to Bahasa Malaysia. This is because we actually have never heard of some of the Malay words that we hear during the lectures. *Sometimes I also ask the lecturers, but not that frequent. *I use Google Translate too, but the translation made by this application is not always accurate.

Respondent $\mathrm{B}$ was found to be utilising several strategies while coping with bilingual instructions. During lectures, he would mentally translate the difficult words while at the same time too try to understand the content of the lectures. Basically, mentally translating words from a language to another is feasible if the words that are to be translated are easy. However, there are some obstacles which might hinder this cognitive process. Firstly, if the meanings of the words in a particular language are already inaccessible to the learners, then the process of mentally translating the words to the other language will be affected or blocked. Secondly, there is also this factor of time constraint. The students do not only have to deal with the difficult terminologies, but also to understand the content of the lectures in that allocated lecture time. In the case of Respondent B however, it can be concluded that he already has the proficiencies in both languages, thus easing his learning. Nonetheless, still, he needed lecturers' assistance in clarifying some words which appeared difficult to him.

As for the strategy he applied to complete the task, he also used the similar strategy of referring to Google Translate like what Respondent A did. However, he regarded this tool as inconsistently reliable. This is because the translation made by it is not always accurate as it only does a direct translation. A direct translation is one that does not take into account the 
context of the text. It therefore leads to the production of the translated words which are not cohesive and do not cohere with thetext.

Respondent C

Saya just translate and at the same time try to understand what the lecturers teach us. Saya slow sikit (la) bila lecturers guna perkataan BM untuk like describe proses-proses (ke). Tanya kawan-kawan pun ada juga. Sebab ada yang faham. Ada yang tak faham. Macam saya, susah sikit nak faham BM words yang lecturers guna (ni). 'Penyahjatan' semua (tu).

TRANSLATION: I will just translate and at the same time try to understand the lectures. I am a bit slow when it comes to understanding the Malay words used by the lecturers to describe things, for example, like describing processes etc. I will also ask my friends because there are some of them who understand those words. But for a person like me, I find it difficult to understand the Malay words used by the lecturers. For example, like the word 'penyahjatan'.

Respondent $\mathrm{C}$ also mentioned the strategy of mentally translating the words during lectures like what Respondent B had pointed out. Since she had problem to understand the Malay words used by the lecturers, finding the equivalent words in English would then be difficult for her.

Respondent D

Owh... tanya kawan sahaja. (Diaorang) pun pandai-pandai. Lagi....saya cari maksud perkataan-perkataan tu dalam kamus. Saya ada kamus Oxford (tu). Tapi guna kamus Oxford (tu) pun susah and tak banyak bantu sangat pun. Okay (je). Tapi sebab definition (tu) macam berbungabunga dalam English, jadi tak berapa specific sangat maksudnya. Yang kita nak definition dalam Sains, bukan English.

TRANSLATION: I will just ask my friends as some of them are clever. Other than that, I will search for the definitions of those words in dictionary. I actually have one Oxford dictionary. But referring to that dictionary does not help that much. It does help in some ways. It is just that the definitions are flowery, making the definition less specified. What I want is the scientific definitions, not English-related ones.

There were two strategies applied by Respondent D. Firstly, she would ask for help from her peers who she regarded as clever. Secondly, she would also refer to dictionaries. However, she commented that referring to dictionaries did not always help her in completing her tasks. This is because the definitions given by the dictionaries do not conceptually explain the meanings of the words. Rather, the definitions are given in a more languagerelated structure.

\section{Question 3}

Could you briefly demonstrate to me on how do you do that? 
This question was specifically asked to Respondent $\mathrm{B}$ as he mentioned that the translation made by the Google Translate application is inaccurate. He came out with a word 'water bath', a biological terminology of which its equivalent word in Bahasa Malaysia is 'takungan air panas'. He demonstrated to the researcher on how he translated the word using this application and the translation proposed by it came out to be 'mandi air'. The translation of this word is clearly incorrect. Therefore, the accuracy and reliability of this translating application is inconsistent. This occurs as this application only makes direct translation without considering the context and the words that are translated.

Respondent B

Contohnya, perkataan 'water bath'. Dalam BM sepatutnya maksudnya takungan air panas. Tapi, sekejab saya 'google translate' perkataan ni. Tengok, translationnya jadi mandi air. So tak betul.

TRANSLATION: For instance, the word 'water bath'. Its equivalent word in Bahasa Malaysia is supposed to be 'takungan air panas'. But let me translate this word first using this Google Translate. See, the translation becomes 'mandi air', so it is not accurate.

\section{Question 4} learning?

Do you find the strategies you have been using helpful to your

Basically most of the respondents answered that the strategies they have been applying to cope with bilingual instructions have been helpful to their learning. However, Respondent B and D who had earlier mentioned about the usage of Google Translate responded that the unreliability and inaccuracy of this application becomes a problem to their learning. As they have little sources of references regarding the definitions of scientific terminologies, they have no choice but to resort to referring to Google Translate. As the translation made by it is inconsistently accurate, they will have to reconfirm with the lecturers about the correct definition/translation.

Respondent A

So far, yes it is helpful. Lecturers selalunya akan explain (la) betulbetul the definition and what not.

TRANSLATION: So far, yes, it has been helpful. Lectures will usually explain the definition and what not.

The answer given by Respondent A tells the researcher that the clarification made by the lecturers regarding students' inquiries were helpful to their learning. Therefore, it can be generalized that making inquiries to lecturers in bilingual teaching environment largely aids students' comprehension about the subject matter.

Respondent B 
Macam yang saya cakap tadi, 'Google Translate' tak berapa nak betul sangat. Kalau betul, memang senang kerja kami.

TRANSLATION: Like what I have said before, the Google Translate application is not that reliable. If it does, it will definitely ease our learning.

The strategy of referring to Google Translate was found to be inconsistently helpful in bilingual teaching environment. Though it does translate words to a target language, its infidelity of translation becomes a factor that makes it unreliable to science students’ learning.

Respondent C

Okay (la). Saya rasa setakat (ni) cara yang saya dah apply untuk faham instructions lecturers (tu) membantu saya (la). So ya... Lagi pun bukan masalah sangat pun, perkataan-perkataan (tu) sahaja. Yang related dengan topic apa yang diajar (tu) saya faham sebenarnya. Perkataanperkataan Melayu (tu) (je) yang kadang-kadang confusing.

TRANSLATION: It is fine. As for now, I find that the strategies that I have applied to understand the lecturers' instructions have been helpful to me. Furthermore, understanding the bilingual instructions is actually not a problem to me. It is just that those Malay words which sometimes confuse me. Things that are related to the topic of science is however understandable.

Respondent $\mathrm{C}$ commented that she was able to cope with bilingual instructions. The strategies that she had applied to comprehend the lectures and complete the tasks were helpful to her learning. It then signifies that this respondent has good proficiencies in both English and Bahasa Malaysia, thus enabling her to benefit from bilingualism.

Respondent D

Overall, membantu. Tapi yang dictionary (tu), tak berapa membantu sangat (la). Kadang-kadang, tak jumpa pun dalam kamus perkataan yang saya cari. Kalau jumpa pun tak berapa faham sangat. And macam tak best (la) kalua setiap kali nak cari perkataan tu, nak refer kamus. Berat pulak (tu).

TRANSLATION: Overall, it does help. But referring to dictionaries is not much of a help though. Sometimes too, I cannot find the words that I am looking for in the dictionary. And even if I find them, it is a little bit difficult for me to understand the definition. Plus, it is not that convenient to use the dictionary when studying. It is heavy.

Respondent D mentioned that the strategies that she had applied so far in coping with bilingual instructions were helpful to her. Only that referring to dictionaries did not offer much of a help in her learning. There were times when the words that she tried to find in the dictionaries were not there. Even if there were, the definitions only explained the words superficially, not the concepts that the words brought. 


\section{Conclusion}

Generally, the strategies can be categorized into two; the strategies applied by the students in order to comprehend the lectures and the strategies they apply in task completion. In order for them to cope with lectures which are delivered in bilingual instructions, firstly, they will mentally translate the words uttered by the lecturers. These are employed as there are some words that are unfamiliar to them. Cummins (2000) states that one can only fully benefit from bilingualism if he or she has adequate proficiencies in both the languages. This means that if a student has not yet attained sufficient proficiencies in the particular two languages, it will be difficult for them to gain the benefits from bilingualism. Another factor that can affect a successful mental translation too is the fact that it is done simultaneously with the action of trying to comprehend the content of the lectures. As the students are expected to be able to grasp what are being taught by the lecturers, they will encounter the difficulty in dealing with the two actions. Therefore, the students will resort to other methods in order to cope with bilingual instructions.

Secondly, the students will also make inquiries to the lecturers when they realize that they are unable to comprehend the terminologies used in the lectures. This strategy is found to be employed by many students as it largely aids their comprehension. Coping with bilingual instructions in task completion on the other hand requires different strategies. From the interviews conducted with the respondents, it was found that they frequently referred to Google Translate when they did not know the meanings of or the equivalent words in the target language.

Next, the students will also refer to dictionaries to find for the definitions of the difficult words. Still, dictionaries cannot best serve the students as the definitions are given in a language-related manner. The students might be able to understand the definitions given, but the concepts that the words bring and how they describe scientific processes are still unclear to them.

As the strategies in coping with bilingual instruction are now found, it will then contribute an insight to the lecturers or the course designers on how to better approach the students in their learning in bilingual environments.

\section{References:}

1. Asiah Mohd Sharif. (2013). Limited Proficiency English Teachers' Language Use in Science Classrooms. GEMA Online ${ }^{\circledR}$ Journal of Language Studies 65 (13):12-32.

2. Baker, C. (2011). Foundation of Bilingual Education and Bilingualism. 
3. http://books.google.com.my/books?hl=en\&lr=\&id=fEt5VKBIMSsC \&oi=fnd\&pg $=$ PR

4. $6 \& d q=$ foundation+of+bilingual+education+and+bilingualism\&ots $=\mathrm{i}$ EUlLtpWMQ\&si

5. $\mathrm{g}=2$ ltxhUrOv5PsZHq9ynzUF6xkvL4\&redir_esc=y\#v=onepage\&q=f oundation\%20of

6. \%20bilingual\%20education\%20and\%20bilingualism\&f=false November 2013]

7. Butler, Y. \& Hakuta, K. (2006). The Handbook of Bilingualism. Blackwell Publishing Ltd.

8. Christian, D. (1994). Two-Way Bilingual Education: Students Learning Through Two Languages. NCRCDSLL Educational Practice Reports, Center for Research on Education, Diversity and Excellence, UC Berkeley.

9. Cummins, J. (2000). Language, Power and Pedagogy. Bilingual Children in the Crossfire. Clevedon: Multilingual Matters.

10. Finch, A. (2009). European Language Education Models: Implications for Korea. English Teaching 64(4): 95-122.

11. Gottardo, A. (2008). Assessment of Reading Acquisition in Bilinguals.

12. http://literacyencyclopedia.ca/index.php?fa=items.show\&topicId=23 7 [retrieved on 17 November 2013]

13. Ha, P.L., Kho, J., \& Chng, B. (2013). Nation Building, English as an International Language, Medium of Instruction, and Language Debate: Malaysia and Possible Ways Forward. Journal of International and Comparative Education 2(2): 43-61

14. Jimenez, R. T. (1997). The Strategic Reading Abilities and Potential of Five Low Literacy Latina/o Readers in Middle School. 32(3): 224243.

15. Lan, O.S. \& Tan, M. (2008). Mathematics and Science in English: Teachers Experience inside the Classroom. Jurnal Pendidik dan Pendidikan Jil. 23: 141-150.

16. Lopez, B. \& Patricia. (1995). Foundations of Bilingual Education and Bilingualism Issues in Applied Linguistics 6(1). 319-335

17. Mackeracher, D. (1996). Making Sense of Adult Learning, Toronto: Culture Concepts.

18. Padron, Y. 1992. The Effect of Strategy Instruction on Bilingual Students' Cognitive Strategy Used in Reading. Bilingual Research Journal 16:3\&4.

19. Padron (1992). The Effect of Strategy Instruction on Bilingual Students' Cognitive Strategy Use in Reading . Bilingual Research Journal, 16:3\&4, Summer/Fall 1992: 35-51 
20. Parilah, M. \& Fauziah, A. (2013). A Comparative Account of the Bilingual Education Programs in Malaysia and the United States. GEMA Online Journal of Language Studies Volume 7(2): 63-77

21. Zare, M. \& Mobarakeh, S. (2013). Effects of Bilingualism on L3 Vocabulary Learning Among Iranian EFL learners. GEMA Online ${ }^{\mathrm{TM}}$ Journal of Language Studies 127 Volume 13(1): 127-138 